\title{
Analisis Perbandingan Kinerja Mach-Zehnder berdasarkan Ragam Format Modulasi pada Jaringan FTTH
}

\author{
ZULIA NURUL KARIMAH ${ }^{1}$, AKHMAD HAMBALI ${ }^{2}$, SUWANDI ${ }^{3}$ \\ 1,2Program Studi S1 Teknik Telekomunikasi Fakultas Teknik Elektro Telkom University \\ 3Program Studi S1 Teknik Fisika Fakultas Teknik Elektro Telkom University \\ Email : zuliaaanurul@gmail.com
}

\begin{abstract}
ABSTRAK
Pada jurnal ini dibuat pemodelan link FTTH pada software Optisystem 7.0 untuk mengetahui pengaruh dari Kerr effect dengan membandingkan performansi serat optik kaca dan serat optik plastik berdasarkan format modulasi berupa $N R Z, R Z$, RZ-DPSK, RZ-DQPSK dan CSRZ. Terdapat dua skenario, dengan skenario pertama, variabel input yang diubah adalah format modulasi pada Mach-zehnder, sedangkan pada skenario kedua, variabel yang diubah adalah pemakaian serat optik yang dipakai, yaitu serat optik bahan kaca, plastik dan hybrid kaca plastik. Hasil simulasi menunjukkan dengan efek linier dan non-linier pada kabel kaca yang menghasilkan performansi jaringan dari yang terbaik, dengan $Q$ factor di atas 6 dan BER di bawah $10^{-9}$ adalah NRZ, RZ, RZ-DPSK, CSRZ dan RZ-DQPSK. Sedangkan dengan penggunaan kabel PMMA, yang menunjukkan performansi jaringan yang baik adalah dengan konfigurasi G652D-G652D-PMMA pada format modulasi NRZ, RZ, RZ-DPSK dan RZ-DQPSK. Efek non-linier yang terjadi pada jaringan ini hanya SPM dan XPM.
\end{abstract}

Kata kunci: FTTH, mach-zehnder, format modulasi, efek non-linier, GOF, POF

\begin{abstract}
In this journal is creating a FTTH link on Optisystem software 7.0 to determine the effect of Kerr effect by comparing the performance of fiber optic glass and plastic optical fiber based on modulation formats such as NRZ, RZ, RZ-DPSK, RZ$D Q P S K$ and CSRZ. There are two scenarios, first, input variables are changed based on format in Mach-zehnder modulator, while in the second scenario, the changed variable is the material of optical fiber, the materials are optical fiber glass, plastic and hybrid plastic and glass. The simulation results based on comparison with linear and nonlinear effects on glass optical fiber, which produce $Q$ factor above 6 and BER below $10^{-9}$ are NRZ, RZ, RZ-DPSK, CSRZ and RZ$D Q P S K$. While the use of PMMA cable, which indicates good network performance is the configuration G652D-G652D-PMMA on the modulation format $N R Z, R Z, R Z-D P S K$ and RZ-DQPSK. Nonlinear effects that occur in this network only SPM and XPM.
\end{abstract}

Keywords: FTTH, mach-zehnder, modulation format, nonlinear effects, GOF, POF 


\section{Pendahuluan}

Serat optik adalah media di mana sinyal komunikasi ditransmisikan dari satu lokasi ke lokasi lain dalam bentuk cahaya melalui serat tipis kaca atau plastik. Serat optik yang terbuat dari kaca terdiri dalam tiga lapisan yaitu inti (core) yang merupakan tempat merambatnya cahaya, lapisan cladding yang merupakan tempat pemantulan cahaya dan membatasi cahaya agar tidak keluar dari inti, serta lapisan coating yang berfungsi untuk melindungi serat optik dari tekanan luar dan kerusakan. Dalam pengaplikasiannya, serat optik kaca rentan patah sehingga serat optik plastik (Plastic Optical Fiber) yang juga disebut serat optik polimer mampu mengatasi hal tersebut dimana serat ini menggunakan PMMA (akrilik) untuk bahan inti, dan polimer fluorinated sebagai bahan cladding (Thorat, 2014). Meskipun serat optik memberikan banyak keuntungan namun terdapat pula kekurangan yang dapat mengganggu kinerja dari serat optik tersebut, yaitu efek yang dapat membatasi pengiriman dan kecepatan pengiriman data. Efek ini terbagi menjadi efek linier dan efek non-linier. Efek linier meliputi redaman dan dispersi. Sedangkan efek non-linier timbul akibat Kerr effect yang berupa Self Phase Modulation (SPM), Cross Phase Modulation (XPM) dan Four Wave Mixing (FWM) serta akibat Inelastic Scattering meliputi Stimulated Raman Scattering (SRS) dan Stimulated Brillouin Scaterring (SBS). Efek non-linier ini dapat merusak sinyal informasi.

Untuk menangani gangguan linier dan non-linier, format modulasi yang optimal menjadi solusinya. Penelitian (Angesti, 2015) telah dibahas mengenai perbandingan kinerja modulator Mach-Zehnder berdasarkan ragam format modulasi untuk sistem komunikasi serat optik kanal tunggal $40 \mathrm{~Gb} / \mathrm{s}$ dan penelitian (Sari, 2015) membahas mengenai perancangan FTTH di PBB I. Pada penelitian ini akan diperdalam mengenai perbandingan kinerja modulator Mach-Zehnder berdasarkan ragam format modulasi dengan medium serat optik non-linier berbahan kaca, plastik maupun hybrid kaca dan plastik menggunakan Coarse Wavelength Digital Multiplexer (CWDM) sebagai multiplexernya di jaringan FTTH PBB I. Format modulasi yang akan diuji adalah Non Return to Zero (NRZ), Return to Zero (RZ), Carrier Surpressed Return to Zero (CSRZ), Return to Zero Differential Phase Shift Keying (RZ-DPSK) dan Return to Zero Differential Quadrature Phase Shift Keying (RZ-DQPSK). Beberapa parameter yang diujikan antara lain PLB, S/N, BER, Q factor dan bentuk pulsa yang dihasilkan.

\subsection{Konsep FTTH}

FTTH merupakan suatu format transmisi sinyal optik dari pusat penyedia (provider) ke kawasan pengguna dengan menggunakan serat optik sebagai media kirimnya. Dalam perancangan jaringan FTTH terdapat batas maksimum agar layanan yang diterima pelanggan tetap dapat diterima dengan baik yaitu $20 \mathrm{~km}$.

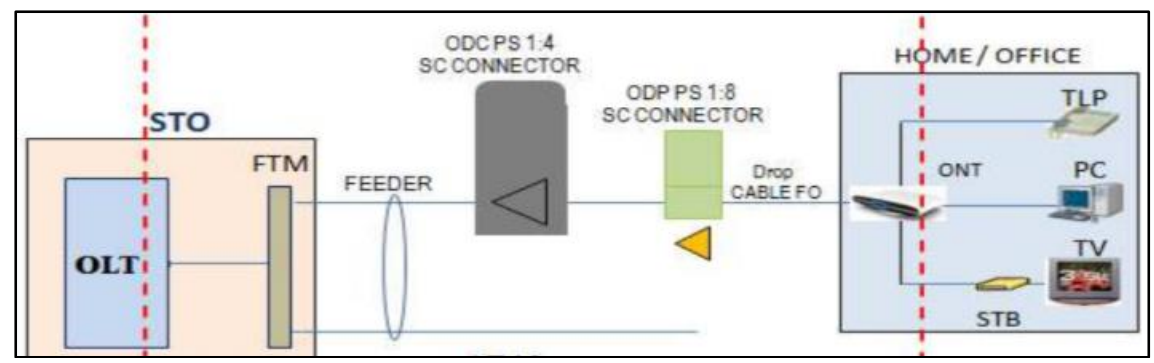

Gambar 1. Konfigurasi Fiber to the Home (PT. Telkom, 2010) 
Konfigurasi FTTH memuat komponen-komponen penting berdasarkan teknologi GPON, yaitu:

a. Optical Line Terminal (OLT)

OLT merupakan perangkat yang berfungsi sebagai penyedia layanan endpoint jaringan optik pasif. OLT diletakkan pada Central Office atau pada saat di lapangan OLT implementasinya berada di STO.

b. Fiber Terminal Management (FTM) atau Optical Distribution Frame (ODF)

Fungsi utamanya yaitu digunakan sebagai interface antara jaringan transmisi optik, peralatan transmisi optik, dan antara kabel optik dalam jaringan akses fiber optik pelanggan.

c. Optical Distribution Cabinet (ODC)

ODC berfungsi sebagai tempat instalasi sambungan jaringan optik single mode yang dapat terdiri dari connector, splicing maupun splitter, dan dilengkapi ruang pengaturan fiber dengan kapasitas tertentu pada jaringan optik pasif (PON) untuk hubungan telekomunikasi.

d. Optical Distribution Cabinet (ODP)

ODP digunakan untuk menghubungkan jaringan distribusi ke pelanggan dan mengatur serat optik serta kabel optik.

e. Optical Network Terminal(ONT)

Perangkat ini digunakan sebagai demodulator dimana akan terjadi proses pengubahan dari sinyal cahaya ke elektris dan sebaliknya.

\subsection{Modulator Mach-Zehnder}

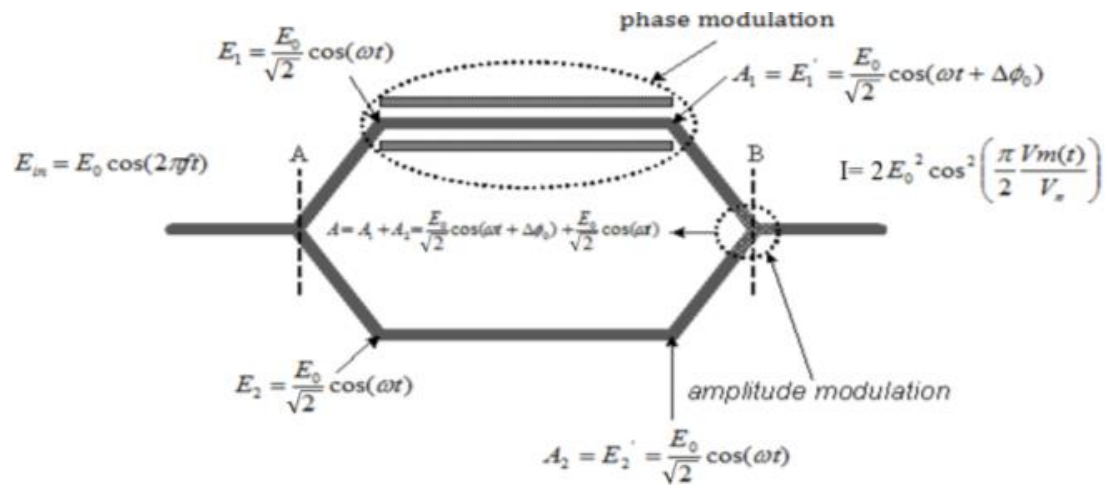

Gambar 2. Proses Modulasi pada Modulator Mach-Zehnder (Saputra, 2010)

Masukan awal yang berupa sinyal cahaya dibagi menjadi dua jalur melalui persimpangan $Y$ yang pertama sehingga menjadi dua sinyal cahaya yang sama besar dan sefasa. Pembagian sinyal ini mempunyai maksud agar salah satu dari pecahan sinyal cahaya tersebut nantinya akan mengalami proses modulasi pada bagian yang terdapat elektroda, sedangkan sinyal cahaya yang berada pada jalur yang lainnya tetap dan tidak termodulasi.

Lengan 1 terdapat elektroda pemodulasi (lengan interaksi), ketika diberi tegangan sebesar $\mathrm{V}(\mathrm{t})$ yang merupakan sinyal pemodulasi maka menyebabkan perubahan fasa gelombang cahaya yang menjalar sepanjang pandu gelombang dan terjadi perubahan indeks bias. Perubahan $\mathrm{V}(\mathrm{t})$ mengakibatkan perubahan indeks bias waveguide yang akan mengakibatkan perubahan fasa. Perubahan fasa ini nantinya akan mempengaruhi karakteristik dari gelombang cahaya yang merambat pada lengan interaksi pertama.

Pada sambungan $\mathrm{Y}$ kedua di modulator Mach-Zehnder, terjadi interferensi antara dua berkas optik dari kedua lengan transisi. Salah satu berkas telah mengalami modulasi fasa, sedangkan berkas lainnya tidak mengalami proses apapun. Kedua berkas tersebut saling 
berinterferensi dan menghasilkan berkas optik dengan karakteristik yang baru. Hasil dari perpaduan kedua berkas cahaya tersebut merupakan keluaran dari modulator Mach-Zehnder yang didapatkan dengan menggunakan prinsip dari interferensi cahaya.

\subsection{Efek Non-linier}

Efek non-linier pada optik timbul akibat respon dari setiap bahan dielektrik terhadap cahaya untuk medan elektromagnetik yang kuat dan terjadi ketika indeks bias dalam medium serat optik berinteraksi dengan intensitas berkas cahaya. Polarisasi $P$ dipengaruhi oleh dipol elektrik yang tidak linier pada medan magnet $\mathrm{E}$, yang didefinisikan seperti persamaan berikut ini (Agrawal, 2001):

$$
\boldsymbol{P}=\varepsilon_{0}\left(X^{(1)} \cdot \boldsymbol{E}+X^{(2)}: \boldsymbol{E} \boldsymbol{E}+X^{(3)} \vdots \boldsymbol{E} \boldsymbol{E} \boldsymbol{E}+\cdots\right)
$$

Di mana $\varepsilon_{0}$ adalah permitivitas vakum, $X^{(1)}$ suseptibilitas linier, $X^{(2)}$ suseptibilitas orde dua seperti second harmonic generation, sum-frequency generation, dan $X^{(3)}$ suseptibilitas orde 3 yang merupakan non-linieritas pada serat. Selain itu, intensitas yang berinteraksi ini menimbulkan efek penghamburan atau disebut fenomena Inelastic Scaterring, yang menghasilkan dua efek, yaitu SBS (Stimulated Brillouin Sccattering) dan SRS (Stimulated Raman Scattering). Interaksi daya pada medium berindeks refraktif berhubungan langsung dengan Kerr effect di mana penyebab adanya Kerr effect adalah indeks bias refraktif yang berubah-ubah akibat intensitas daya optik, fenomena tersebut ditujukan dalam rumus di bawah ini (Agrawal, 2002):

$$
\phi=n \omega L=\frac{2 \pi n L}{\lambda}=\frac{2 \pi}{\lambda}\left(n_{0}+n_{2} I\right) L=\text { constant }+\phi_{N L}
$$

di mana phasa non linier pada optik (Agrawal, 2002):

$$
\phi_{N L}=\frac{2 \pi n_{2} I L}{\lambda}
$$

Dalam level daya sinyal yang lebih banyak, Kerr-effect pada non-linier bermanifestasi menjadi tiga bentuk modulasi yaitu Self-Phase Modulation (SPM), Cross-Phase Modulation (XPM) dan Four-Wave Mixing (FWM).

Selain itu, perhitungan koefisien indeks bias non-linier dapat diolah melalui persamaan di bawah ini (Agrawal, 2001):

$$
\mathrm{n}_{2}=\frac{3}{8 \mathrm{n}} \operatorname{Re}\left(\mathrm{X}_{\mathrm{xxxx}}^{(3)}\right)
$$

Dimana $n_{2}$ adalah koefisien indeks bias non-linier, $\mathrm{n}$ adalah indeks bias refraktif dan $\operatorname{Re}\left(X_{x x x x}^{(3)}\right)$ adalah bagian real dari third-order susceptibility yang bertanggung jawab terhadap fenomena seperti FWM dan refraksi non-linier dan memberikan kontribusi terhadap indeks bias refraktif. Satuan untuk $n_{2}$ adalah $\mathrm{m}^{2} / \mathrm{W}$. Namun terkadang digunakan satuan esu (electrostatic unit), sehingga perlu perngkonversian dari satuan esu ke unit SI dengan menggunakan persamaan sebagai berikut (Agrawal, 2001):

$$
n_{2}\left(m^{2} / w\right)=\frac{80 \pi}{c n}\left(n_{2}(e s u)\right)
$$

\subsection{Power Link Budget}

Power Link Budget digunakan untuk mengetahui batasan redaman total yang diizinkan antara daya keluaran pemancar dan sensitivitas penerima pada suatu link sistem komunikasi serat optik (Sari, 2015). Dapat juga dilakukan untuk mengetahui besarnya penurunan atau pelemahan daya pada jarak tertentu. Setelah dilakukan perhitungan Power Link Budget, dapat diketahui pelemahan daya terdapat pada jarak berapa sehingga dapat dipasang penguat daya pada jarak yang dianggap terjadi penurunan daya yang signifikan. 
Besar redaman total tersebut diperhitungkan dari redaman konektor, redaman sambungan (redaman splicer), dan redaman dari serat itu sendiri sehingga dengan perhitungan redaman tersebut akan berpengaruh pada:

1. Jarak transmisi pengirim dan penerima

2. Jumlah repeateryang dibutuhkan

3. Margin loss yang diberikan

Perhitungan Power Link Budget menggunakan rumus sebagai berikut (Sari, 2015):

Maka,

$$
\alpha_{\text {tot }}=L . \alpha_{\text {kabel }}+N c . \alpha_{c}+N s . \alpha_{s}+S p+M
$$

$$
\operatorname{Pr} x=P t x-\alpha_{t o t}
$$

Adapun dikenal redudancy atau margin system. Bentuk persamaan untuk perhitungan margin daya adalah sebagai berikut (Sari, 2015):

$$
M=(P t x-P r x)-\alpha_{t o t}-S M
$$

Keterangan:

$\begin{array}{lllll}\boldsymbol{\alpha}_{\text {tot }} & : \text { redaman total sistem }(\mathrm{dB}) & \mathrm{Nc} & : \text { jumlah konektor } \\ \boldsymbol{\alpha}_{\text {kabel }} & : \text { redaman kabel optik }(\mathrm{dB} / \mathrm{Km}) & \mathrm{Ns} & : \text { jumlah sambungan } \\ \boldsymbol{\alpha}_{\mathbf{c}} & : \text { redaman konektor }(\mathrm{dB} / \mathrm{buah}) & \mathrm{M} & : \text { margin }(\mathrm{dB}) \\ \boldsymbol{\alpha}_{\mathrm{s}} & : \text { redaman sambungan }(\mathrm{dB} / \text { sambungan) } & \mathrm{Prx} & : \text { daya pengirim }(\mathrm{dBm}) \\ \mathrm{Sp} & : \text { redaman } \operatorname{splitter}(\mathrm{dB}) & \mathrm{Ptx} & : \text { daya penerima }(\mathrm{dBm}) \\ \mathrm{L} & : \text { panjang serat optik }(\mathrm{Km}) & \mathrm{SM} & : \text { safety margin }(6-8 \mathrm{~dB})\end{array}$

\subsection{Kualitas Transmisi (S/N)}

Dalam menentukan kualitas transmisi digunakan parameter Signal to Noise Ratio $(\mathrm{S} / \mathrm{N})$ atau Bit Error Rate (BER). S/N merupakan perbandingan antara daya sinyal tehadap daya noise pada satu titik yang sama, dapat dirumuskan sebagai berikut:

$$
\text { Signal }- \text { to }- \text { Noise Ratio }\left(\frac{S}{N}\right)=\frac{\text { Signal Power }}{\text { Shot noise }+ \text { noise dark current }+ \text { thermal noise }}
$$

Perhitungan daya sinyal (signal power) dan daya noise (noise power) adalah sebagai berikut:

\section{a. Daya Sinyal (Signal Power)}

Daya sinyal merupakan kuat daya sinyal yang diterima pada receiver. Besar daya sinyal di penerima ditujukan dengan persamaan berikut (Agrawal, 2001):

$$
\begin{aligned}
& \text { Signal Power }=\left\langle I_{p}{ }^{2}\right\rangle M^{2} \\
& \text { Signal Power }=\left(\frac{\eta q}{h v} P_{r}\right)^{2} M^{2}
\end{aligned}
$$




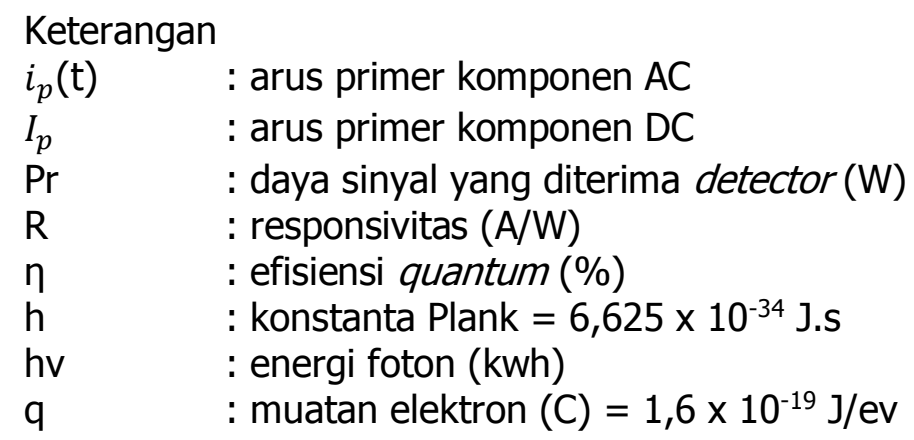

b. Derau (noise)

Derau adalah sinyal-sinyal yang tidak diinginkan yang selalu ada dalam suatu sistem transmisi. Level noise yang cukup besar akan terasa menggangu pada sisi penerima. Sumbangan daya noise di detector cahaya (receiver) pada sistem komunikasi serat optik ada 3 macam yaitu: thermal noise, noise dark current dan shot noise (Ali, 2015).

\section{Shot Noise}

Cahaya dari foton merupakan paket energi diskrit. Derau tembakan terjadi karena adanya ketidaklinearan pada sistem. Dengan demikian, waktu tiba yang acak dari tiap foton menyebabkan komponen noise acak pada arus output dari fotodioda, yang disebut shot noise. Shot noise sebanding dengan harga rata-rata sinyal optik. Daya shot noise adalah sesuai persamaan (Ali, 2015):

$$
\left\langle i_{Q}{ }^{2}\right\rangle=2 q I_{p} B M^{2} F(M)
$$

Keterangan

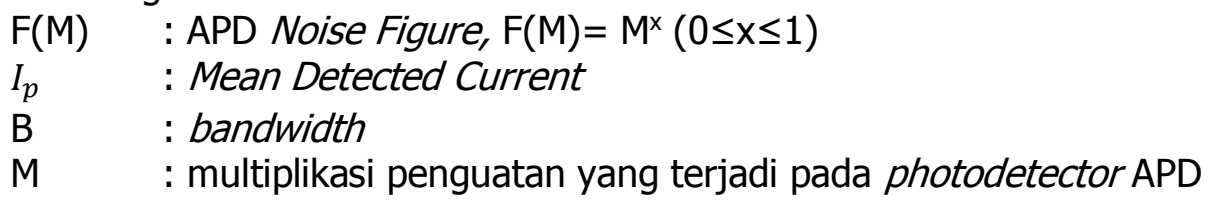

\section{Dark Current Noise}

Walaupun pada kegelapan absolut, ada arus yang sangat kecil dari fotodioda yang diakibatkan efek bocor yang berubah-ubah. Arus gelap yaitu arus balik (reverse current) kecil yang mengalir melalui persikap balik (reverse bias diode). Arus gelap ini terjadi pada setiap dioda yang dikenal dengan arus bocor balik (reverse leakage current). Sumbangan arus gelap terhadap daya noise dirumuskan menjadi dua tipe derau, yaitu dark bulk current (Ali, 2015):

$$
\left\langle i_{D B}{ }^{2}\right\rangle=2 q I_{D} B M^{2} F(M)
$$

Dan reverse leakage current (Ali, 2015):

$$
\left\langle i_{D s}{ }^{2}\right\rangle=2 q I_{L} B
$$


Keterangan

$i_{D B} \quad$ : dark bulk current noise

$i_{D S} \quad$ : surface leakage current noise

$I_{D} \quad:$ arus gelap

$I_{L} \quad$ : arus bocor

3. Thermal Noise

Thermal noise adalah arus yang berasal dari struktur gerak acak elektron bebas pada komponen-komponen elektronik. Noise thermal disebabkan oleh elemen resistif pada penguat penerima. Biasanya level noise ini sebanding dengan temperatur pada sistem komunikasi serat optik. Besar daya noise thermal dirumuskan sebagai berikut (Ali, 2015):

Keterangan

$$
\left\langle i_{T}{ }^{2}\right\rangle=\frac{4 k_{B} T B}{R_{L}}
$$

$k_{B} \quad:$ konstanta Boltzman $(\mathrm{J} / \mathrm{K})=1,38 \times 10^{-23} \mathrm{~J} /{ }^{\circ} \mathrm{K}$

Teff : effective noise temperatur $\left({ }^{\circ} \mathrm{k}\right)$

$\mathrm{R}_{\mathrm{L}} \quad$ : impedansi beban penerima $(\Omega)$

\section{Q Factor}

Q factor adalah faktor kualitas yang akan menentukan bagus atau tidaknya kualitas suatu link. Dalam sistem komunikasi serat optik, minimal ukuran Q factor yang bagus adalah 6 .

\section{BER ( Bit Error Rate)}

BER merupakan perbandingan bit yang error dengan bit yang dikirim. Bit yang error dapat disebabkan oleh gangguan, interferensi, dispersi, dll. Untuk teknologi komunikasi optik maksimum nilai BER-nya adalah $10^{-9}$ (Mott, 2000). Hubungan antara Q factor dan BER adalah (Agrawal, 2002):

$$
B E R=\frac{1}{2} \operatorname{erfc}\left(\frac{Q}{\sqrt{2}}\right)
$$

Di mana erfc merupakan fungsi error dengan rumus (Agrawal, 2002):

$$
\operatorname{erfc}(x)=\frac{1}{\sqrt{2 \pi}} \int_{x}^{\infty} e^{\left(\frac{-x^{2}}{2}\right)} d x
$$

Sedangkan hubungan antara S/N dan BER adalah (Tanjung, 2015):

$$
(\mathrm{S} / \mathrm{N}) \mathrm{pk} / \mathrm{rms}=20 \log 2 \mathrm{Q}
$$

Sehingga diperoleh nilai pendekatan (Wang, 2005):

Keterangan

$$
B E R=P e(Q)=\frac{1}{\sqrt{2 \pi}} \frac{e^{-\frac{Q^{2}}{2}}}{Q}
$$

Q : $Q$ factor

$\mathrm{Pe} \quad$ : error probability 


\section{PERANCANGAN DAN SIMULASI}

\subsection{Pemetaan Jarak Rute Kabel}

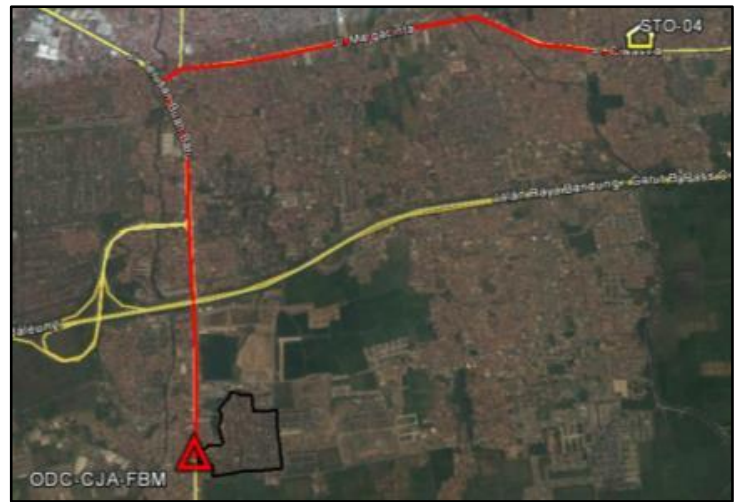

(a)

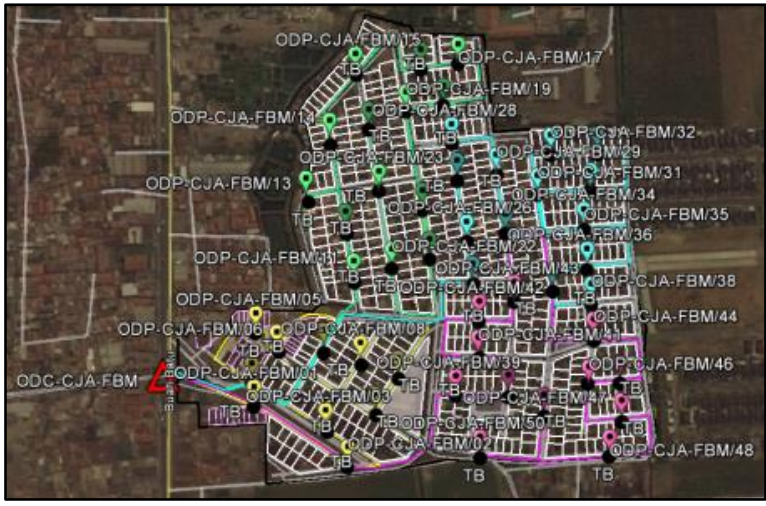

(b)

Gambar 3. Rute Kabel (a) Feeder (b) Distribusi

Pengukuran jarak dilakukan menggunakan software Google Earth dari STO yang terdapat perangkat OLT dan FTM, ke ODC, dari ODC ke ODP, dan dari ODP akan diarahkan menuju roset di rumah pelanggan, yang kemudian berakhir di ONT. Sehingga, jarak total terjauh yang didapatkan adalah sepanjang $6.161,84 \mathrm{~m}$ dengan panjang kabel feeder 4,84 km, kabel distribusi 1224,11 m dan kabel drop 97,73 m.

STO Cijaura dipilih sebagai catuan sumber PBB I karena masuk dalam wilayah cakupannya. Berbeda dengan perancangan jaringan eksisting di STO dan ODC, untuk peletakan ODP yang menggunakan hasil gambar AutoCAD peletakan perangkat jenis ini didasari pada pemilihan kelompok rumah yang disesuaikan dengan posisi baris rumah yang dibangun. Dalam satu OPD mencakup 8 atau 16 rumah, bergantung splitter yang digunakan pada ODP tersebut dan pemetaan rumah yang dibuat seefisien mungkin. Selanjutnya untuk peletakan ODP dipilih lokasi yang tidak mengganggu mobilisasi pelanggan perumahan dan diletakkan di pertengahan atau di rumah paling awal, hal ini dimaksudkan supaya redaman yang terukur tidak besar.

\subsection{Blok Simulasi OLT sampai ONT}

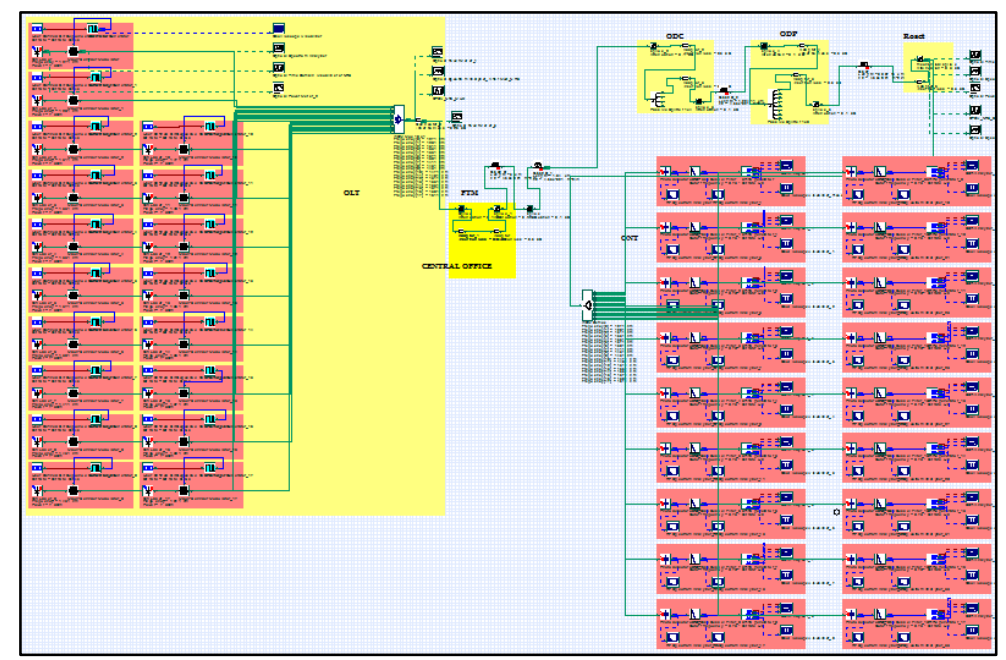

Gambar 4. Blok simulasi OLT sampai dengan ONT dengan format modulasi NRZ 
Pada perancangan ini digunakan User Defined Bit Generator untuk masukan bit yang dikirim. Bit yang dikirim terdiri dari 4 bit yaitu 1011, penggunaan 4 bit ini agar pada grafik, pulsa yang terkirim dapat terlihat jelas. Pada transmitter digunakan frequency spacing sebesar 20 $\mathrm{nm}$, frekuensi yang digunakan yaitu 18 kanal frekuensi CWDM tiap simulasi. Sinyal yang keluar dari OLT dengan panjang gelombang berbeda akan masuk multiplexer kemudian di transmisikan melalui blok kabel feeder. Konektor yang digunakan memiliki redaman masingmasing $0.25 \mathrm{~dB}$ dan redaman fiber optik menggunakan redaman tertinggi dari panjang gelombang yang digunakan. Sepanjang STO hingga kesisi ODC digunakan kabel feeder yang sesuai dengan standar ITU-T jenis G.652.

Blok ODC terdapat komponen splitter 1:4 yang mempunyai redaman $7.25 \mathrm{~dB}$. Terkadang ketika di dalam perangkat terminasi, untuk menghubungkan dua konektor digunakan adaptor, jadi dalam pengukuran nilai link budgetnya memiliki nilai redaman terpisah yang berbeda dengan nilai redaman sebuah konektor, dengan nilai redaman sebesar $0.5 \mathrm{~dB}$.

Kabel serat optik yang dipakai terdiri dari dua bahan yaitu serat optik berbahan kaca dan serat optik berbahan plastik. Serat kaca yang digunakan memiliki indeks bias 1,44967 (Frosz, 2009) sedangkan serat plastik yang digunakan adalah serat plastik dengan jenis PMMA (Polymethyl methacrylate) dengan indeks bias 1,4795 (Frosz, 2009). Dengan indeks bias 1,44967 dan $X^{(3)}$ sebesar $3,1 \times 10^{-14}$ esu (Frosz, 2009), maka pada penelitian ini digunakan serat optik kaca yang memiliki indeks bias non-linier $\left(n_{2}\right)$ sebesar $4,63 \times 10^{-21} \mathrm{~m}^{2} / W$ dan dengan indeks bias 1,4795 dan $\mathrm{X}^{(3)}$ sebesar $7 \times 10^{-14}$ esu (Frosz, 2009), maka indeks bias non-linier $\left(n_{2}\right)$ serat optik plastik sebesar $10,05 \times 10^{-21} \mathrm{~m}^{2} / \mathrm{W}$.

Pada blok ONT terdapat blok demultiplexer yang berfungsi untuk memecah kembali panjang gelombang untuk masuk ke proses konversi dari daya optis ke elektrik agar bisa dianalisis melalui BER Analyzer. Blok ONT terdiri dari ODP yang memuat blok slice, adaptor, splitter 1:8 dan ditransmiskan melalui kabel drop yang bertugas mendistribusikan sampai masuk ke rumah pelanggan dimana kabel drop optik yang dipakai tipe G.657 atau diganti dengan PMMA. Setelah itu masuk ke detektor yang merupakan ONT, demultiplexer untuk memecah kanal, Photodetector APD sebagai detektor optik, Low Pass Bessel Filter sebagai filter, 3R Regenerator, serta BER Analyzer untuk menganalisis nilai BER dan $Q$ factor.

\subsection{Blok Format Modulasi}

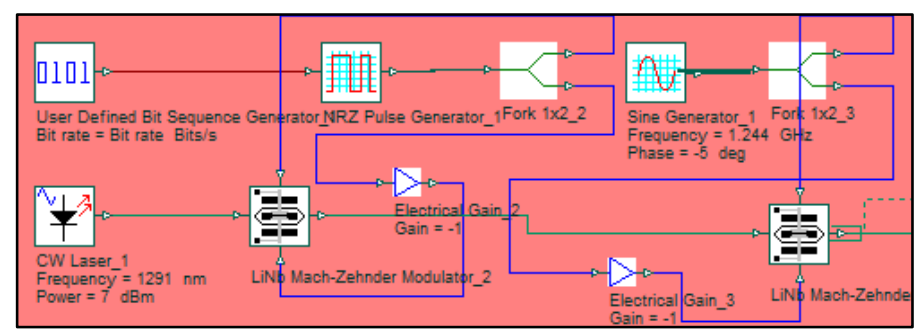

Gambar 5. Format Modulasi CSRZ

Gambar 5 di atas menunjukkan konfigurasi CSRZ. Dalam membangkitkan sinyal CSRZ dibutuhkan dua modulator optik. Modulator intensitas pertama berfungsi untuk membangkitkan sinyal NRZ dan modulator fasa yang kedua berfungsi untuk menghasilkan beda fasa optik sebesar $n$ antara bit yang berdekatan (Angesti, 2015). 


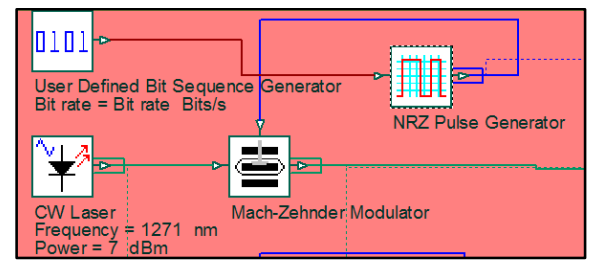

\section{Gambar 6. Format Modulasi NRZ}

Gambar 6 di atas menunjukkan konfigurasi NRZ. Dalam konfigurasi ini digunakan beberapa komponen optik seperti NRZ pulse generator, yang akan membangkitkan pulsa NRZ, modulator Mach Zehnder dan juga sumber cahaya LASER (Angesti, 2015).

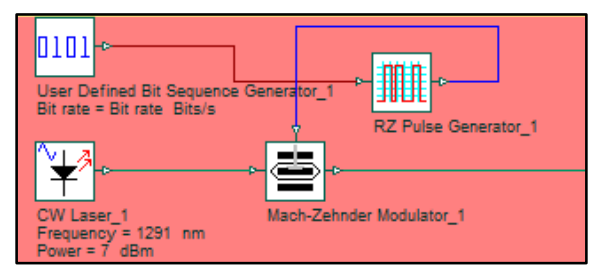

\section{Gambar 7. Format Modulasi RZ}

Gambar 7 di atas menunjukkan konfigurasi RZ. Konfigurasi format modulasi RZ membutuhkan komponen berupa RZ pulse generator, sumber cahaya LASER dan modulator Mach-Zehnder. Modulator ini berfungsi untuk membangkitkan sinyal RZ (Angesti, 2015).

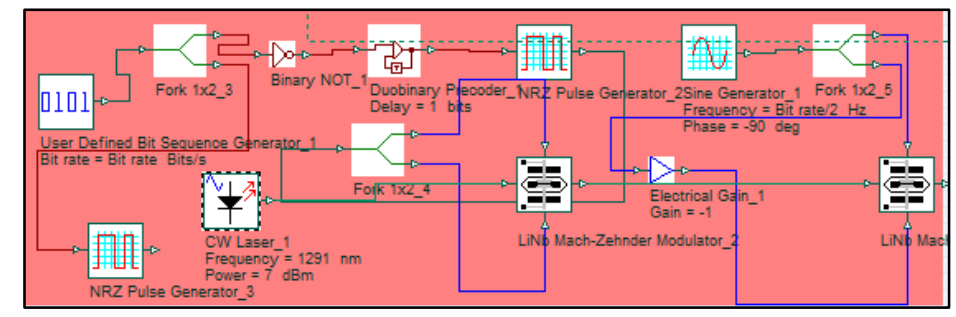

Gambar 8. Format Modulasi RZ-DPSK

Gambar 8 di atas menunjukkan konfigurasi RZ-DPSK. Untuk membangkitkan sinyal optik RZDPSK dipasang NRZ generator, sine wave dan dua modulator Mach-Zehnder. Sinyal optik NRZ-DPSK akan dihasilkan setelah keluar dari modulator pertama. Kemudian sinyal NRZDPSK ini akan disampling dengan runtutan pulsa periodik pada modulator kedua sehingga akan mendapatkan sinyal optik RZ-DPSK (Angesti, 2015).

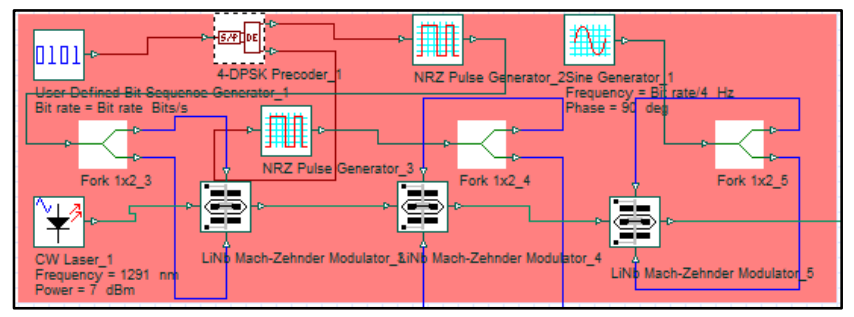

Gambar 9. Format Modulasi RZ-DQPSK

Gambar 9 di atas menunjukkan konfigurasi RZ-DQPSK. Untuk membangkitkan sinyal optik RZ-DQPSK dipasang 3 modulator Mach-Zehnder. Modulator pertama dan kedua berfungsi untuk membangkitkan dua sinyal terkodekan dan termodulasi dan menghasilkan sinyal DQPSK. Modulator ketiga kemudian akan membangkitkan sinyal RZ sehingga sinyal optik RZDQPSK akan terbentuk (Angesti, 2015). 


\section{HASIL DAN DISKUSI}

\subsection{Analisis Q factor dan BER Simulasi Ragam Format Modulasi}

Jaringan FITH dengan konfigurasi kabel kaca diberi masukan lima format modulasi yang berbeda pada input modulator Mach-Zehnder yang selanjutnya akan diuji apakah kelima format modulasi tersebut layak untuk dipakai pada konfigurasi FTTH. Jika tiap format modulasi dapat memenuhi kelayakan link dengan Q factor di atas 6 dan BER di bawah $10^{-9}$ maka format modulasi tersebut akan diimplementasikan di konfigurasi kabel plastik.

Tabel 1. Performansi Simulasi Tiap Format Modulasi

\begin{tabular}{|c|c|c|c|c|}
\hline \multirow{2}{*}{ Format Modulasi } & \multicolumn{2}{|c|}{ Min } & \multicolumn{2}{c|}{ Average } \\
\cline { 2 - 5 } & Q Factor & BER & Q Factor & BER \\
\hline CSRZ & 9,343135232 & $4,27137 \mathrm{E}-09$ & 11,54402293 & $2,37298 \mathrm{E}-10$ \\
\hline NRZ & 57,6898 & 0 & 65,51885 & 0 \\
\hline RZ & 45,20828894 & 0 & 51,75991714 & 0 \\
\hline RZ-DPSK & 11,7584 & $2,27556 \mathrm{E}-32$ & 14,2882614 & $1,26448 \mathrm{E}-33$ \\
\hline RZ-DQPSK & 6,11974 & $1,57679 \mathrm{E}-10$ & 9,226723333 & $1,19351 \mathrm{E}-11$ \\
\hline
\end{tabular}

Pada Tabel 1 terlihat bahwa semua format modulasi dengan efek linier dan non-linier telah memenuhi nilai $Q$ factor yang ditentukan, yaitu lebih dari 6 dan layak untuk digunakan dalam sistem komunikasi serat optik, dengan nilai $Q$ factor rata-rata berturut-turut dari yang terbesar yaitu NRZ dengan nilai 65,51885, RZ dengan nilai 51,75991714, RZ-DPSK dengan nilai 14,2882614, CSRZ dengan nilai 11,54402293 dan RZ-DQPSK dengan nilai 9,2267233. Pada parameter Q factor, NRZ memiliki nilai Q factor terbesar, begitu halnya dengan BER, nilai BER akan berbanding terbalik dengan nilai $Q$ factor, semakin besar nilai $Q$ factor maka tingkat kesalahan performasi jaringan akan semakin kecil.

\subsection{Analisis Bentuk Sinyal Bit Kirim dan Terima}

Bit awal yang dikirim terdiri dari 4 bit, yaitu 1011 dengan pengaturan di setiap format modulasinya mempunyai panjang rentetan bit sebesar 64 bit dengan sampel per bit nya adalah sebanyak 64. Masing-masing format modulasi memiliki bentuk sinyal termodulasi yang berbeda-beda sesuai dengan blok diagram tiap format modulasi.

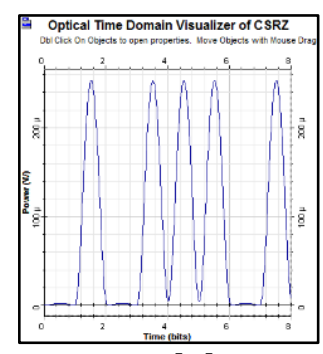

(a)

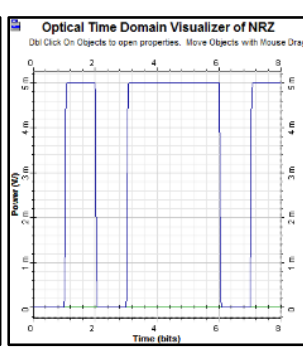

(b)

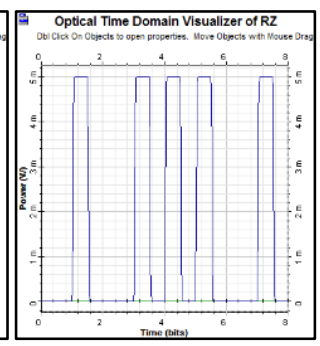

(c)

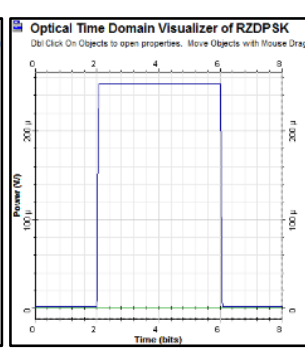

(d)

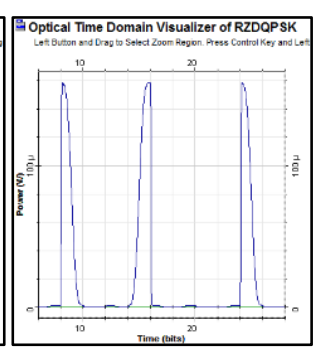

(e)

Gambar 10. Bit termodulasi (a) CSRZ 8 sampel (b) NRZ 8 sampel (c) RZ 8 sampel (d) RZ-DPSK 8 sampel (e) RZ-DQPSK 20 sampel

Gambar 10.(a) menunjukkan format modulasi CSRZ, menghasilkan delay selama 1 bit lalu mulai dari bit ke-1 sampai seterusnya menunjukkan bentuk sinyal amplitudo tinggi untuk bit "1" dan amplitudo yang rendah utuk bit "0".

Gambar 10.(b) menunjukkan format modulasi NRZ dimana bit sinyal kirim mengalami delay selama satu periode bit, kemudian bentuk sinyal mulai dari periode bit ke satu sampai 
seterusnya menunjukkan bentuk sinyal biner 1011. Dalam format modulasi NRZ ini per bit nya tidak kembali ke level nol.

Gambar 10.(c) menunjukkan format modulasi RZ dimana bit sinyal kirim mengalami delay selama satu periode bit, kemudian bentuk sinyal mulai dari periode bit ke satu sampai seterusnya menunjukkan bentuk sinyal biner 1011. Dalam format modulasi RZ ini per bit nya kembali ke level nol, sehingga membutuhkan bandwidth yang lebih lebar.

Gambar 10.(d) menunjukkan format modulasi RZ-DPSK dengan data biner di-encode sebagai perubahan fasa sebesar " 0 " atau " $"$ ". Sebelum memasuki modulator fasa eksternal, dalam hal ini adalah mach zehnder, sinyal NRZ elektrik harus di pre-encode terlebih dahulu oleh encoder DPSK. Dalam sebuah encoder DPSK, data NRZ digabungkan dengan sinyal itu sendiri yang telah di-delay sebanyak satu bit dengan menggunakan gerbang XOR. Sinyal elektik yang telah dikodekan ini kemudian digunakan untuk mengendalikan modulator elektro-optik mach zehnder untuk menghasilkan sebuah sinyal optik DPSK. Sebuah bit "1" dilambangkan dengan sebuah perubahan fasa sebesar $\Pi$ pada sinyal data berikutnya. Sebaliknya, ketika tidak ada perubahan fasa pada data berikutnya berarti data yang dikirim adalah bit "0". Untuk menghasilkan sinyal optik RZ-DPSK, dibutuhkan satu lagi modulator intensitas dibandingkan dengan NRZ-DPSK untuk memodulasi sinyal clock dengan data rate yang sama dengan sinyal elektrik yang melalui modulator intensitas.

Gambar 10.(e) menunjukkan format modulasi RZ-DQPSK dimana bit sinyal kirim mengalami delay selama enam periode bit. Setelah itu, dilanjutkan dengan susunan biner 1101 lainnya dengan masing-masing bit mempunyai panjang 4 periode bit dengan setengah periode bit untuk level tinggi atau rendah diikuti setengah periode selanjutnya kembali ke level nol. Namun di setiap awal bit " 1 ", terjadi delay selama 2 periode bit. Modulasi dengan jenis pengkodean format RZ-DQPSK ini merubah fasa dari bit 10 menjadi 11 dan bit 11 menjadi 10 .

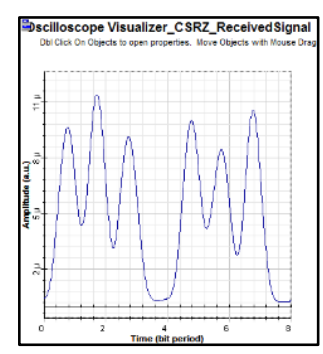

(a)

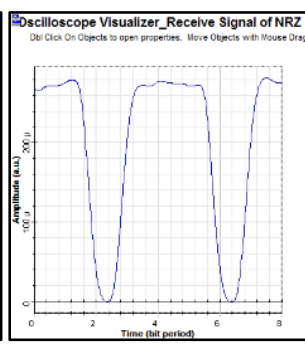

(b)

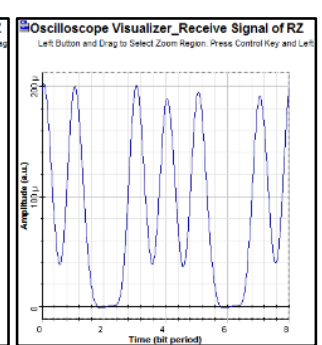

(c)

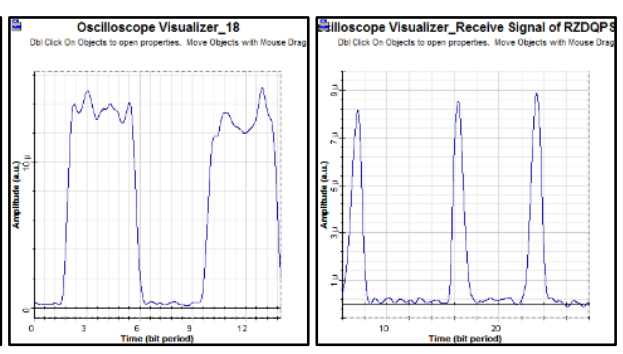

(d)

(e)

Gambar 11. Bit terima (a) CSRZ 8 sampel (b) NRZ 8 sampel (c) RZ 8 sampel (d) RZ-DPSK 8 sampel (e) RZ-DQPSK 20 sampel

Gambar 11.(a) menunjukkan bentuk sinyal terima di penerima dengan format modulasi CSRZ, terdapat informasi yang tidak sesuai dengan data yang dikirimkan pada awal bit yaitu ditunjukkan bit dengan level tinggi selama 2,2 periode bit. Bentuk bit yang sesuai dengan data informasi yang dikirimkan adalah dimulai dari periode bit ke-2,2 bit sampai dengan periode bit ke-6,2 bit. Hal ini bisa terjadi karena adanya delay pada saat data dikirimkan.

Gambar 11.(b) menunjukkan bentuk sinyal terima di penerima dengan format modulasi NRZ. Bentuk sinyal terima dengan format modulasi NRZ adalah bentuk sinyal yang paling mirip dengan bentuk sinyal informasi yang dikirim. Walaupun terdapat informasi yang tidak sesuai 
dengan data informasi selama 0,8 periode bit tapi tidak terlalu berpengaruh terhadap kualitas transmisi. Bit terima yang sesuai dengan representasi bit kirim berada pada periode bit 0,8 sampai dengan 4,8 . Amplitudo sinyal yang dihasilkan pada pengkodean NRZ ini menghasilkan amplitudo yang paling tinggi diantara keempat format modulasi lainnya.

Gambar 11.(c) menunjukkan bentuk sinyal terima di penerima dengan format modulasi RZ. Bentuk sinyal terima format modulasi RZ menunjukkan bentuk sinyal yang mirip dengan bentuk sinyal informasi yang dikirim. Namun, sama halnya dengan format modulasi CSRZ dan NRZ, pada format modulasi RZ terdapat informasi yang tidak dibutuhkan pada awal bit selama 0,6 periode bit. Bit terima yang sesuai dengan representasi bit kirim berada pada periode bit 0.6 bit sampai dengan 4,6 bit. Amplitudo sinyal yang dihasilkan tinggi namun masih berada di bawah pengkodean NRZ.

Gambar 11.(d) menunjukkan bahwa bentuk sinyal terima dengan format modulasi RZ-DPSK tidak sesuai dengan bentuk sinyal informasi. Pola bit pada sisi receiver ini menghasilkan bentuk 00001111 dan seterusnya, mengikuti bentuk dari bit modulasi namun periode bit nya 2x lipatnya. Walaupun begitu, amplitudo sinyal yang dihasilkan lebih besar dibandingkan dengan CSRZ dan lebih kecil dibandingkan dengan NRZ dan RZ.

Gambar 11.(e) menunjukkan bentuk sinyal terima di penerima dengan format modulasi RZDQPSK. Sama halnya dengan pengkodean CSRZ, NRZ, dan RZ pada awal bit terima terdapat bit yang tidak sesuai dengan data infromasi selama 4 periode bit. Selanjutnya pola yang terlihat sesuai dengan bentuk data informasi yang sebenarnya adalah bit-bit yang berada pada periode bit ke- 6 bit sampai dengan ke-28 bit sesuai dengan gambar 11.(e). Namun di akhir setiap bit 1 selalu diakhiri dengan delay sepanjang 4 periode bit. Walaupun besarnya amplitudo yang dihasilkan tidak tetap, namun semakin banyak bit yang diterima semakin tinggi amplitudonya.

Dapat disimpulkan bahwa dari bentuk sinyal terima kelima format modulasi yang menunjukkan bentuk sinyal yang paling mendekati dengan bentuk sinyal informasinya dan amplitudo yang tinggi adalah yang menggunakan pengkodean NRZ, sedangkan sebaliknya format modulasi yang terburuk adalah pengkodean RZ-DQPSK, karena selain bentuk sinyal terima yang tidak terlalu mirip dengan bit sinyal informasi, juga amplitudo sinyal yang dihasilkan adalah yang paling kecil. Kemudian urutan format modulasi yang terbaik berdasarkan bentuk sinyal terima dan amplitudonya adalah NRZ, RZ, CSRZ, RZ-DPSK, dan terakhir RZ-DQPSK.

\subsection{Perhitungan Power Link Budget}

Perhitungan power link budget pada penelitian ini hanya didasarkan pada arah downlink dengan jarak dari sentral ke pelanggan yang paling jauh. Perhitungan power link budget dilakukan untuk mengetahui redaman total yang diizinkan antara daya keluaran pemancar dan sensitivitas penerima. Perhitungan power link budget dilakukan berdasarkan standarisasi ITU-T, yaitu jarak yang tidak lebih dari $20 \mathrm{~km}$ dengan batas redaman total $28 \mathrm{~dB}$. 
Tabel 2. Power Link Budget Tiap Konfigurasi Kabel

\begin{tabular}{|c|c|c|c|c|c|}
\hline \multicolumn{3}{|c|}{ Kabel } & \multirow{2}{*}{$\alpha_{t o t}(\mathrm{~dB})$} & \multirow{2}{*}{$P_{R x}(\mathrm{dBm})$} & \multirow{2}{*}{$M(\mathrm{~dB})$} \\
\hline Feeder & Distribusi & Drop & & & \\
\hline G652D & G652D & G657 & 24,806644 & $-17,806644$ & 5,193356 \\
\hline G652D & G652D & PMMA & 30,1475885 & $-23,1475885$ & $-0,1475885$ \\
\hline G652D & PMMA & G657 & 91,7042555 & $-84,7042555$ & $-61,7042555$ \\
\hline G652D & PMMA & PMMA & 97,0452 & $-90,0452$ & $-67,0452$ \\
\hline PMMA & G652D & G657 & 308,5284385 & $-301,5284385$ & $-278,5284385$ \\
\hline PMMA & G652D & PMMA & 294,6535885 & $-287,6535885$ & $-264,6535885$ \\
\hline PMMA & PMMA & G657 & 356,2102555 & $-349,2102555$ & $-326,2102555$ \\
\hline PMMA & PMMA & PMMA & 361,5512 & $-354,5512$ & $-331,5512$ \\
\hline
\end{tabular}

Berdasarkan hasil perhitungan PLB di atas, untuk konfigurasi kabel G652D-G652D-G657 didapatkan nilai redaman total di bawah nilai redaman maksimal yang ditentukan oleh ITU-T serta PT. Telkom, yaitu sebesar $28 \mathrm{~dB}$, maka link ini memenuhi syarat dari sisi total redaman. Nilai $P_{r x}$ harus lebih besar atau sama dengan sensitivitas detektor agar penerima dapat bekerja dengan baik. Pada konfigurasi kabel ini, didapatkan nilai daya terima receiver $\left(P_{\text {rx }}\right)$ sebesar $-17,806644 \mathrm{dBm}$. Hal ini masih memenuhi persyaratan dari perangkat untuk nilai minimum daya terima yaitu sebesar $-29 \mathrm{dBm}$ dan ketentuan dari ITU-T dan PT. Telkom, yaitu nilai minimum untuk daya terima adalah sebesar $-27 \mathrm{dBm}$. Nilai $\mathrm{M}$ yang didapatkan dari perhitungan tersebut masih berada di atas 0 (nol). Hal tersebut mengindikasikan bahwa konfigurasi dengan kabel tersebut memenuhi kelayakan power link budget.

Untuk konfigurasi kabel G652D-G652D-PMMA, didapatkan nilai redaman total di atas nilai redaman maksimal yang ditentukan, maka link ini tidak memenuhi syarat dari sisi total redaman. Namun, nilai $\mathrm{P}_{\mathrm{rx}}$ pada konfigurasi kabel ini, didapatkan nilai daya terima receiver $\left(P_{\text {rx }}\right)$ sebesar $-23,1475885 \mathrm{dBm}$. Hal ini masih memenuhi persyaratan dari perangkat untuk nilai minimum daya terima. Nilai $M$ yang didapatkan dari perhitungan tersebut berada di bawah 0 (nol). Hal tersebut mengindikasikan bahwa konfigurasi dengan kabel tersebut tidak memenuhi kelayakan power link budget, namun sinyal yang dikirimkan masih dapat diterima pada sisi pelanggan.

Untuk konfigurasi kabel G652D-PMMA-G657, G652D-PMMA-PMMA, PMMA- G652D-G657, PMMA-G652D-PMMA, PMMA-PMMA-G657, dan PMMA-PMMA-PMMA, berdasarkan hasil perhitungan didapatkan redaman total link yang sangat besar dan nilai margin berada di atas nol, sehingga disimpulkan bahwa konfigurasi kabel tersebut tidak memenuhi kelayakan power link budget.

\subsection{Perhitungan Parameter Kualitas Transmisi}

Dalam menentukan kualitas transmisi digunakan parameter signal to noise ratio $(\mathrm{S} / \mathrm{N})$ atau Bit Error Rate (BER). S/N merupakan perbandingan antara daya sinyal tehadap daya noise pada satu titik yang sama. Standarisasi untuk S/N berdasarkan standar PT. Telkom yaitu di atas $21,5 \mathrm{~dB}$ dan di bawah $10^{-9}$ untuk BER. Semakin meningkatnya $S / N$, maka akan mengakibatkan atau kecepatan error menjadi berkurang, sehingga kualitas performansi jaringan akan semakin meningkat. Perhitungan S/N dan BER dilakukan di setiap konfigurasi kabel. 
Tabel 3. Kualitas Transmisi Tiap Konfigurasi Kabel

\begin{tabular}{|c|c|c|c|c|c|}
\hline \multicolumn{3}{|c|}{ Kabel } & \multirow{2}{*}{$S / N(d B)$} & \multirow{2}{*}{$\mathbf{Q}$} & \multirow{2}{*}{ BER } \\
\hline Feeder & Distribusi & Drop & & & \\
\hline G652D & G652D & G657 & 35,19680969 & 28,7614309 & 4,9094E-179 \\
\hline G652D & G652D & PMMA & 28,71282485 & 13,63362194 & $8,89478 \mathrm{E}-42$ \\
\hline G652D & PMMA & G657 & $-89,9210193$ & $1,59558 \mathrm{E}-05$ & 24324,20472 \\
\hline G652D & PMMA & PMMA & $-100,602904$ & $4,66471 \mathrm{E}-06$ & 83201,83075 \\
\hline PMMA & G652D & G657 & $-523,19448$ & $3,46135 \mathrm{E}-27$ & $1,17073 \mathrm{E}+26$ \\
\hline PMMA & G652D & PMMA & $-495,44478$ & $8,44755 \mathrm{E}-26$ & $4,79702 \mathrm{E}+24$ \\
\hline PMMA & PMMA & G657 & $-618,933013$ & $5,65353 \mathrm{E}-32$ & $6,86497 \mathrm{E}+30$ \\
\hline PMMA & PMMA & PMMA & $-629,614902$ & $1,65282 \mathrm{E}-32$ & $2,34819 \mathrm{E}+31$ \\
\hline
\end{tabular}

Berdasarkan hasil perhitungan kualitas performansi jaringan masing-masing konfigurasi kabel, yang menunjukkan hasil $\mathrm{S} / \mathrm{N}$ di atas $21,5 \mathrm{~dB}$ dan BER di bawah angka $10^{-9}$ adalah konfigurasi kabel G652D-G652D-G657 dan G652D-G652D-PMMA, dengan perolehan nilai sebesar 4,9094E-179 dan 8,89478E-42. Sedangkan untuk konfigurasi lainnya, yaitu G652DPMMA-G657, G652D-PMMA-PMMA, PMMA-G652D-G657, PMMA-G653D-PMMA, PMMA-PMMAG657, dan PMMA-PMMA-PMMA menghasilkan nilai BER di atas nilai $10^{-9}$, sehingga performansi konfigurasi tersebut buruk karena perbandingan daya dan sinyal yang kecil dan tingkat kesalahan yang besar.

\subsection{Analisis Simulasi Performansi dengan Penggunaan Kabel PMMA}

Berdasarkan analisis sebelumnya dengan menggunakan konfigurasi kabel kaca menunjukkan bahwa seluruh format modulasi telah menunjukkan kualitas link yang baik, dimana menghasilkan Q factor di atas 6 dan BER di bawah $10^{-9}$. Selanjutnya, kelima format modulasi tersebut diuji dengan penggantian dari kabel kaca ke kabel plastik dan hybrid kaca dan plastik berdasarkan hasil Q factor apakah menghasilkan kualitas yang baik atau tidak mengingat kabel plastik mempunyai redaman yang sangat besar.

Tabel 4. Hasil Kualitas Transmisi dengan Kabel PMMA

\begin{tabular}{|c|c|c|c|c|c|}
\hline \multirow{2}{*}{ Format Modulasi } & \multicolumn{3}{|c|}{ Kabel } & \multirow{2}{*}{ Q Factor } & \multirow{2}{*}{ BER } \\
\cline { 2 - 5 } & Feeder & Distribusi & Drop & 5,627383333 & $5,39059 \mathrm{E}-08$ \\
\hline CSRZ & G652D & G652D & PMMA & 5,62730 \\
\hline NRZ & G652D & G652D & PMMA & 36,43096111 & $2,7225 \mathrm{E}-225$ \\
\hline RZ & G652D & G652D & PMMA & 28,26062222 & $1,6042 \mathrm{E}-127$ \\
\hline \multirow{2}{*}{ RZ-DPSK } & G652D & G652D & PMMA & 6,694168333 & $7,51477 \mathrm{E}-10$ \\
\cline { 2 - 6 } & G652D & PMMA & G657 & 0,32141 & 1 \\
\hline RZ-DQPSK & G652D & G652D & PMMA & 6,029402778 & $1,07647 \mathrm{E}-06$ \\
\hline
\end{tabular}

Tabel 4 menunjukkan bahwa pada setiap format modulasi tidak dapat mengirimkan data sampai ke penerima dan mengalami kualitas transmisi yang buruk sehingga didapatkan nilai $\mathrm{Q}$ factor bernilai nol dan BERnya bernilai satu dengan konfigurasi kabel G652D-PMMA-G657, PMMA-G652D-G657, PMMA-G652D-PMMA, PMMA-PMMA-G657, dan PMMA-PMMA-PMMA. Hal tersebut terjadi dikarenakan efek linier dan non-linier, salah satunya adalah besarnya redaman kabel yang dimiliki oleh kabel PMMA, dimana semakin besar redaman dan panjang kabel maka akan memperngaruhi kualitas transmisi pada suatu link optik.

Dengan konfigurasi kabel drop menggunakan kabel PMMA, untuk pengkodean jenis CSRZ tidak mampu menghasilkan kualitas transmisi yang baik sehingga didapatkan nilai Q factor di bawah 6 dan BERnya di atas 10-9. Sedangkan untuk empat format modulasi lainnya mampu mengirimkan informasi sampai dengan penerima dan menghasilkan nilai Q factor lebih dari 6 dan BER yang kurang dari 10-9. Sehingga dapat dikatakan penggunaan PMMA di kabel drop 
dapat menjadi alternatif lain untuk digunakan dalam jaringan $\mathrm{FTTH}$ untuk format modulasi NRZ, RZ, RZ-DPSK dan RZ-DQPSK.

Pada konfigurasi kabel G652D-PMMA-G657 dengan format modulasi RZ-DPSK, dapat memberikan nilai $\mathrm{Q}$ factor lebih dari nol, walaupun tidak sesuai dengan kualitas transmisi yang ideal, dimana untuk $Q$ factor sebesar 0,32141. Sehingga dapat dikatakan pengkodean RZ-DPSK lebih unggul dibanding format modulasi lainnya untuk konfigurasi G652D-PMMAG657, karena format modulasi ini mampu menggunakan kabel PMMA di bagian kabel distribusi yang notabenenya format modulasi lain tidak dapat menggunakan konfigurasi kabel ini dan menghasilkan kualitas transmisi yang buruk.

\subsection{Analisis Efek FWM}

Efek FWM merupakan salah satu bentuk efek non-linier dimana setelah data ditransmisikan, muncul panjang gelombang yang tidak diinginkan yang jumlahnya menyesuaikan dengan panjang gelombang yang dikirim. Jumlah panjang gelombang yang tidak dinginkan bisa bernilai sama ataupun berbeda dengan panjang gelombang yang dikirim, apabila sama maka akan bersifat destruktif dan mengurangi nilai $Q$ factor dan BER pun semakin tinggi. Penelitian ini menguji pembangkitan efek non-linier pada jumlah lamda 18 dengan spasi 20 $\mathrm{nm}$ dan membandingkan hal tersebut pada saat panjang gelombang digabungkan menjadi satu dengan pada saat sebelum panjang gelombang dipecah menjadi beberapa kanal. Sehingga Optical Spectrum Analyzer diletakkan di blok setelah multiplexing dan sebelum demultiplexing.

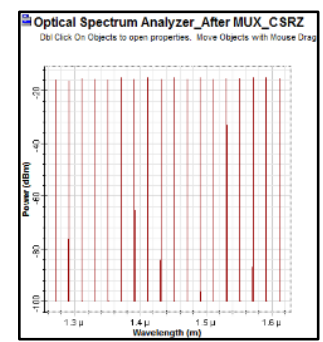

(a)

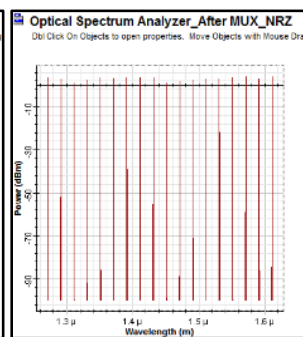

(b)

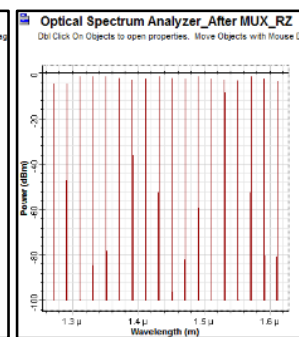

(c)

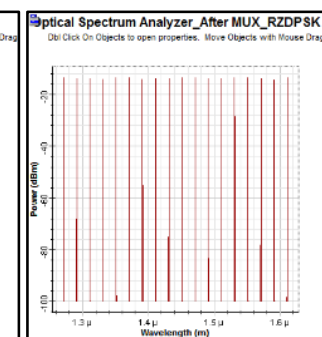

(d)

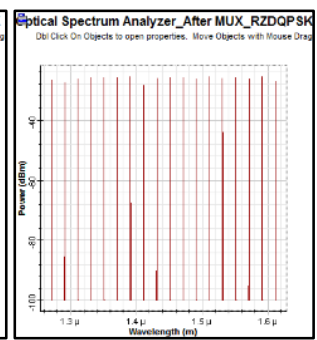

(e)

Gambar 12. Panjang gelombang setelah komponen multiplexer pada format modulasi (a) CSRZ (b) NRZ (c) RZ (d) RZ-DPSK (e) RZ-DQPSK

Pada Gambar 12 terlihat pada setiap format modulasi, OSA diletakkan pada jarak $0 \mathrm{~km}$, setelah panjang gelombang digabungkan menjadi satu dan kemudian diamati jumlah panjang gelombangnya. Jumlah panjang gelombang saat dikirimkan pada setiap format modulasi adalah sebanyak 18 panjang gelombang.

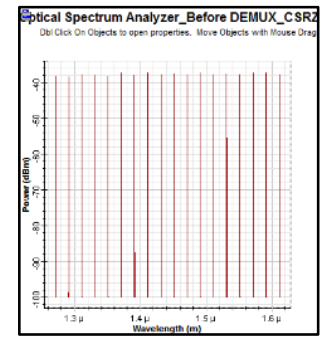

(a)

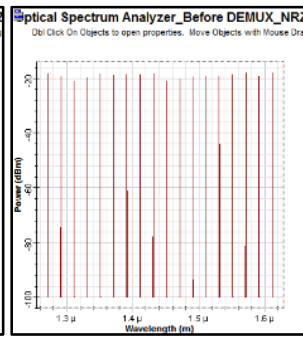

(b)

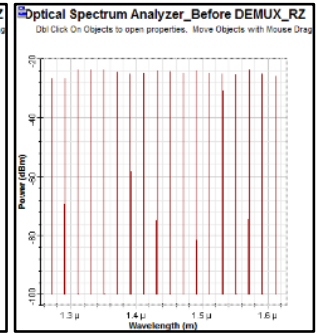

(c)

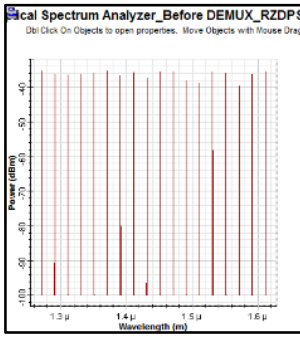

(d)

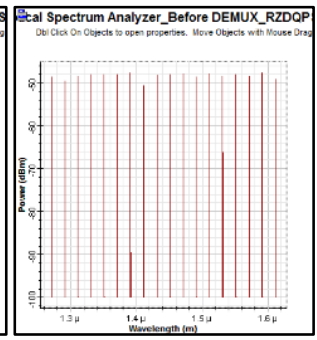

(e)

Gambar 13. Panjang gelombang sebelum komponen demultiplexerpada format modulasi (a) CSRZ (b) NRZ (c) RZ (d) RZ-DPSK (e) RZ-DQPSK 
Pada Gambar 13 terlihat pada jumlah kanal informasi sebanyak 18 panjang gelombang, di bagian sebelum komponen demultiplexer pada masing-masing format modulasi tidak muncul panjang gelombang yang tidak diinginkan, dimana panjang gelombang tetap berjumlah sebanyak 18 kanal, sehingga tidak mempengaruhi Q factor dan BER pada penerima akibat efek FWM. Sehingga dapat disimpulkan bahwa pada jaringan FTTH ini tidak terjadi efek FWM, melainkan dikarenakan Kerr Effect lainnya, yaitu SPM dan XPM.

\subsection{Analisis Perubahan Indeks Bias Non-linier $\left(\mathbf{n}_{\mathbf{2}}\right)$}

Pada analisis sebelumnya, dengan penggantian jenis kabel serat optik plastik di tiap konfigurasi format modulasi berdasarkan efek linier dan non-linier, menghasilkan kualitas transmisi yang lebih buruk dibanding dengan penggunaan jenis kabel serat optik kaca. Pada analisis ini yang dilakukan adalah menghilangkan efek linier dan hanya mengaktifkan efek SPM, dimana efek ini erat kaitannya dengan indeks bias non-linier. Indeks bias non-linier serat optik kaca bernilai $4.63 \times 10^{-21}$ sedangkan indeks bias non-linier serat optik plastik bernilai $10,05 \times 10^{-21}$.

Tabel 5. Hasil kualitas transmisi dengan $\mathbf{n}_{2}$ yang berbeda

\begin{tabular}{|c|c|c|c|l|l|}
\hline \multirow{2}{*}{ Format Modulasi } & \multicolumn{3}{|c|}{ Kabel } & \multicolumn{1}{c|}{ Efek SPM (n2) } \\
\cline { 2 - 6 } & Feeder & Dist. & Drop & Q Factor & \multicolumn{1}{c|}{ BER } \\
\hline \multirow{2}{*}{ CSRZ } & G652D & G652D & G657 & 14,84678333 & $4,82915 \mathrm{E}-35$ \\
\cline { 2 - 6 } & PMMA & PMMA & PMMA & 13,85831111 & $1,4903 \mathrm{E}-35$ \\
\hline \multirow{2}{*}{ NRZ } & G652D & G652D & G657 & 81,23547778 & 0 \\
\cline { 2 - 6 } & PMMA & PMMA & PMMA & 79,79073333 & 0 \\
\hline \multirow{2}{*}{ RZ } & G652D & G652D & G657 & 66,82333889 & 0 \\
\cline { 2 - 6 } & PMMA & PMMA & PMMA & 64,48285556 & 0 \\
\hline \multirow{2}{*}{ RZ-DPSK } & G652D & G652D & G657 & 18,753505 & $8,73906 \mathrm{E}-56$ \\
\cline { 2 - 6 } & PMMA & PMMA & PMMA & 18,26129444 & $1,14523 \mathrm{E}-50$ \\
\hline \multirow{2}{*}{ RZ-DQPSK } & G652D & G652D & G657 & 11,608175 & $7,32463 \mathrm{E}-16$ \\
\cline { 2 - 6 } & PMMA & PMMA & PMMA & 11,24310444 & $5,03913 \mathrm{E}-15$ \\
\hline
\end{tabular}

Dari Tabel 5 pada setiap format modulasi menunjukkan bahwa semakin besar nilai $n_{2}$ maka kualitas transmisi akan semakin buruk. Dengan penggunaan $\mathrm{n}_{2}$ yang lebih besar dan menghilangkan efek linier, kelima format modulasi tetap menunjukkan kualitas transmisi yang baik. Perubahan indeks bias non-liner artinya merubah indeks bias core yang sangat berpengaruh pada proses transmisi, baik dari segi dispersi maupun redaman, perubahan tersebut dapat mengurangi jumlah lamda yang bisa ditransmisikan.

\subsection{Analisis Efek SPM dan XPM}

Efek XPM tidak dapat dipisahkan dengan efek SPM karena keduanya sama-sama berpengaruh terhadap intensitas daya sinyal. Efek SPM mengakibatkan terjadinya fluktuasi daya sinyal pada propagasi satu kanal sedangkan efek XPM mengakibatkan terjadinya silang intensitas daya sinyal pada satu propagasi kanal terhadap propagasi kanal lainnya. Pada analisis ini hanya dilakukan pengamatan dari perbandingan hasil Q factor dengan hanya mengaktifkan efek SPM dan mengaktifkan efek SPM dibarengi efek XPM pada seluruh format modulasi di konfigurasi kabel kaca dan plastik. 
Tabel 6. Efek SPM dan XPM pada Serat Optik Kaca dan Plastik

\begin{tabular}{|c|c|c|c|c|c|}
\hline \multirow{2}{*}{$\begin{array}{c}\text { Format } \\
\text { Modulasi }\end{array}$} & \multirow{2}{*}{ Q Factor } & \multicolumn{2}{|c|}{ Serat Optik Kaca } & \multicolumn{2}{c|}{ Serat Optik Plastik } \\
\cline { 3 - 6 } & & Efek SPM & $\begin{array}{c}\text { Efek SPM dan } \\
\text { XPM }\end{array}$ & Efek SPM & $\begin{array}{c}\text { Efek SPM dan } \\
\text { XPM }\end{array}$ \\
\hline \multirow{3}{*}{ CSRZ } & Minimum & 12,0497 & 13,2035 & 12,1514 & 12,5142 \\
\cline { 2 - 6 } & Maksimum & 18,0465 & 17,3029 & 16,1896 & 17,2381 \\
\cline { 2 - 6 } & Rata-rata & 14,8467833 & 14,63635 & 13,858311 & 14,88663333 \\
\hline \multirow{3}{*}{ NRZ } & Minimum & 71,2645 & 67,7662 & 70,4883 & 89,9047 \\
\cline { 2 - 6 } & Maksimum & 102,283 & 89,4865 & 95,7334 & 89,9047 \\
\cline { 2 - 6 } & Rata-rata & 81,23547 & 76,644738 & 79,790733 & 78,639183 \\
\hline \multirow{3}{*}{ RZ } & Minimum & 49,2598 & 56,4447 & 55,9746 & 58,9591 \\
\cline { 2 - 6 } & Maksimum & 74,4842 & 81,1051 & 75,2975 & 78,6463 \\
\cline { 2 - 6 } & Rata-rata & 66,823338 & 64,485094 & 64,48285 & 67,531122 \\
\hline \multirow{3}{*}{ RZ-DPSK } & Minimum & 14,7056 & 16,506 & 15,489 & 15,6002 \\
\cline { 2 - 6 } & Maksimum & 23,2751 & 22,5731 & 22,7843 & 22,9679 \\
\cline { 2 - 6 } & Rata-rata & 18,753505 & 18,26129 & 18,26129444 & 18,734072 \\
\hline \multirow{3}{*}{ RZ-DQPSK } & Minimum & 7,5231 & 8,5242 & 6,88776 & 8,30684 \\
\cline { 2 - 6 } & Maksimum & 15,2343 & 15,416 & 16,1469 & 18,2375 \\
\cline { 2 - 6 } & Rata-rata & 11,608175 & 10,890190 & 11,243104 & 11,288907 \\
\hline
\end{tabular}

Tabel 6 menunjukkan penggunaan kabel kaca dan plastik dengan efek SPM dan XPM dengan mengabaikan efek linier menghasilkan bahwa seluruh jumlah lamda dapat ditransmisikan, dengan nilai Q factor di atas 6. Fenomena ini membuktikan bahwa pada konfigurasi jaringan FTTH ini, Kerr effect pada serat non-linier tidak membatasi jumlah lamda yang ditransmisikan.

Pada serat optik kaca, terlihat bahwa simulasi dengan penambahan efek non-linier XPM walaupun tidak menunjukkan perbedaan hasil $\mathrm{Q}$ factor yang signifikan namun terlihat performansi jaringan yang menurun pada setiap format modulasi, dengan perbedaan nilai $\mathrm{Q}$ factor dari yang terbesar adalah NRZ dengan selisih nilai 4,590732, RZ dengan 2,33824, RZDQPSK dengan 0,717985, RZ-DPSK dengan 0,492215 dan terakhir CSRZ dengan 0,228433.

Pada serat optik plastik, dengan indeks bias nonlinear yang lebih besar dari kaca, menunjukkan bahwa dengan penambahan efek non-linier XPM, performansi jaringan meningkat pada empat format modulasi, yaitu pada CSRZ, RZ, RZ-DPSK dan RZ-DQPSK. Sedangkan pada format modulasi NRZ, terlihat bahwa Q factor menurun walaupun penurunannya tidak terjadi secara signifikan.

\section{KESIMPULAN}

Melalu hasil simulasi dan perhitungan yang telah dilakukan, dapat diambil beberapa kesimpulan, yaitu:

1. Berdasarkan perbandingan lima format modulasi dengan efek linier dan non-linier pada kabel kaca urutan nilai Q factor dari yang terbesar adalah NRZ, RZ, RZ-DPSK, CSRZ dan RZ-DQPSK dengan bentuk sinyal bit terima yang mendekati dengan bentuk sinyal bit kirim adalah format modulasi NRZ, RZ, CSRZ, RZ-DPSK dan terakhir RZ-DQPSK.

2. Pada perhitungan power link budget sesuai perhitungan downstream dari OLT hingga ONT terjauh, konfigurasi kabel yang dinyatakan layak dari segi redaman, sensitivitas penerima dan margin adalah G652D-G652D-G657, sedangkan untuk kabel G652DG652D-PMMA dinyatakan layak hanya dari segi sensitivitas penerima. 
3. Pada perhitungan kualitas transmisi jaringan masing-masing konfigurasi kabel, yang menunjukkan hasil BER di bawah angka $10^{-9}$ adalah konfigurasi kabel G652D-G652DG657 dan G652D-G652D-PMMA. Penggunaan kabel PMMA yang menghasilkan Q factor di atas 6 pada simulasi adalah dengan konfigurasi G652D-G652D-PMMA pada format modulasi NRZ, RZ, RZ-DPSK dan RZ-DQPSK.

4. Efek Four Wave Mixing (FWM) tidak muncul dalam perancangan $\mathrm{FTTH}$, sehingga tidak muncul panjang gelombang lain yang tidak diinginkan dalam sistem. Perubahan nilai indeks bias non-linier $\left(n_{2}\right)$ sangat berpengaruh terhadap performansi jaringan, semakin besar nilai indeks bias non-linier maka performansi jaringan akan semakin menurun. Pada perancangan FTTH ini tidak mengalami pembatasan jumlah lamda yang ditransmisikan dikarenakan spasi channel yang renggang. Dengan membandingkan simulasi dengan dan tanpa efek XPM memperlihatkan bahwa pada serat optik kaca pada format modulasi NRZ, RZ, RZ-DPSK, RZ-DQPSK dan CSRZ terjadi penurunan kualitas transmisi saat diberi efek XPM. Sedangkan pada serat optik plastik terjadi peningkatan kualitas transmisi saat diberi efek XPM pada CSRZ, RZ, RZ-DPSK dan RZDQPK. Sebaliknya pada format modulasi NRZ terjadi penurunan kualitas transmisi saat diberi efek XPM dengan konfigurasi kabel serat optik plastik.

\section{DAFTAR RUJUKAN}

Agrawal, G. P. (2001). Nonlinear Fiber Optics. University of Rochester New York.

Agrawal, G.P. (2002). Fiber-Optic Communications Systems. University of Rochester New York.

Ali, Mazin Ali A. (2015). Comparison of Modulation Techniques for Underwater Optical Wireless Communication Employing APD Receivers. Iraq.

Angesti, Wildand, Imam Santoso, dan Ajub Ajulian Zahra. (2015). Simulasi Kinerja Modulator Optik Tipe Mach Zehnder Berdasarkan Ragam Format Modulasi. Semarang.

Frosz, M. H., Nielsen, K., Hlubina, P., Stefani, A., \& Bang, O. (2009). Dispersion-engineered and Highlynonlinear Microstructured Polymer Optical Fibres. Technical University Denmark.

Mott, William H., Robert B. Sheldon. (2000). Laser Satellite Communication: The Third Generation. Greenwood Publishing Group.

PT.Telekomunikasi Indonesia Tbk, Direktorat Network dan Solution. (2010). Pedoman Pemasangan Jaringan Akses Fiber Optik. PT. Telekomunikasi Indonesia Tbk. Bandung.

Saputra, Wayan. (2010). Model dan Simulasi Modulator Mach Zehnder untuk Aplikasi Wireless LAN IEEE 802.11g Over Fiber Menggunakan C++. Bandung.

Sari, Velessitas Mega Puspita. (2015). Perancangan Jaringan Akses Fiber to the Home (FTTH) dengan Teknologi Gigabit Passive Optical Network (GPON) di Wilayah Permata Buah Batu I dan II. Bandung. 
Tanjung, Fajri. (2015). Perancangan Jaringan Fiber to The Home (FTTH) Menggunakan Teknologi Coarse Wavelength Division Multiplexing (CWDM) untuk Perumahan Pesona Ciwastra Village Bandung. Bandung.

Thorat, Dr. P. V., Sandhya Warulkar, P. A. Thombre. (2014). Plastic Optical Fiber. India.

Wang, Fengqiu. (2005). Picosecond Pulse Generation and Its Applications in High-Speed Optical Time Division Multiplexing Systems. Churchill College. 